\title{
Cyanotoxin Analysis and Amino Acid Profiles of Cyanobacterial Food Items from Chad
}

\author{
J. S. Metcalf ${ }^{1}$ • R. A. Dunlop ${ }^{1}$ - S. A. Banack ${ }^{1}$ - N. R. Souza ${ }^{1}$ • P. A. Cox ${ }^{1}$
}

Received: 29 November 2019 / Revised: 28 May 2020 / Accepted: 10 June 2020 / Published online: 11 July 2020

(C) The Author(s) 2020

\begin{abstract}
In some parts of the world, cyanobacteria are used as a food in the human diet, due to their ready availability. Lake Chad, has long been a traditional site for the collection of Arthrospira fusiformis which is dried and processed at the lake into thin wafers called Dihé for later consumption or is transported to market for sale. However, Dihé purchased from markets in Chad has not been analyzed for known cyanobacterial toxins or assessed for total amino acid content. Since BMAA in traditional foodstuffs of the indigenous Chamorro people of Guam causes neurodegenerative illness, it is important that Dihe from Chad be analyzed for this neurotoxin. BMAA and its isomer AEG were not detected in our analyses, but a further isomer DAB was detected as both a free and bound amino acid, with an increase in the free concentration after acid hydrolysis of this fraction. Microcystins were present in 6 samples at up to $20 \mu \mathrm{g} / \mathrm{g}$ according to UPLC-PDA, although their presence could not be confirmed using PCR for known microcystin synthetic genes. Amino acid analysis of the cyanobacterial material from Chad showed the presence of large amounts of canonical amino acids, suggesting that this may supplement indigenous people on low protein diets, although regular monitoring of the foodstuffs for the presence of cyanotoxins should be performed.
\end{abstract}

Keywords Chad $\cdot$ Cyanobacteria $\cdot$ Toxins $\cdot$ Nutrition $\cdot$ Microcystin $\cdot$ Neurodegenerative disease

\section{Introduction}

Cyanobacteria, photosynthetic Gram-negative bacteria which appeared early in the earth's geological record, are essential for ecosystem function and health (Stal 2007). However, when environmental conditions allow, such as with the provision of excess nutrients, then mass populations of cyanobacteria can occur (Smith et al. 1999). Often termed cyanobacterial blooms and scums, they can be unsightly and may produce taste and odor compounds, in addition to being capable of producing a wide range of highly toxic compounds that have been linked to both long- and short-term adverse human health events (Metcalf and Codd 2012; Wood 2016; Mello et al. 2018; Janssen 2019). Many cyanobacterial genera are capable of producing toxins, largely delineated according to their mode of action. These include the microcystins and nodularins, cyclic peptide hepatotoxins, cylindrospermopsins,

J. S. Metcalf

james@ethnomedicine.org

Brain Chemistry Labs, Box 3464, Jackson, WY 83001, USA cytotoxic guanidine alkaloids and the alkaloid neurotoxins, anatoxin-a and anatoxin-a(S), as examples (Metcalf and Codd 2012; Wood 2016; Mello et al. 2018; Huisman et al. 2018). In marine and freshwater environments where cyanobacteria are common, such toxins can be highly toxic to aquatic organisms (Sun et al. 2012; Paerl et al. 2016; Huisman et al. 2018; Gene et al. 2019; Shahmohamadloo et al. 2020).

Although cyanobacteria have the potential to produce toxins, increasingly genera such as Aphanizomenon and Spirulina (potentially including Arthrospira) are being promoted as health food supplements (Bishop and Zubeck 2012). Toxin analysis of such supplements has indicated that they are capable of producing a range of toxins, including microcystins, anatoxin-a and $\beta-N$-methylamino-L-alanine (BMAA) (Rawn et al. 2007; Rellán et al. 2009; Heussner et al. 2012; Glover et al. 2015; Roy-LaChapelle et al. 2017). The presence of toxins in health food supplements is a potential risk to consumers, such that in the State of Oregon, commercial products of Aphanizomenon flos-aquae are legislated to not contain microcystins at a concentration of greater than $1 \mu \mathrm{g} / \mathrm{g}$ (Marsan et al. 2017). 
The Republic of Chad is a landlocked African country, and the population of this country is considered to be undernourished and in poverty (World Food Programme 2019). Within this country, Lake Chad (Fig. 1) naturally supports blooms of a cyanobacterium identified by Abulqader et al. (2000) as Arthrospira platensis, now named Arthrospira fusiformis (Voronichin; Komárek et Lund 1990; Sili et al. 2012). This photosynthetic, non-nitrogen fixing prokaryote is harvested by local indigenous women and bloom material is processed for subsequent consumption and sale (Fig. 2a), an activity that is believed to date back to perhaps the ninth century (Abulqader et al. 2000). In Lake Chad, cyanobacteria are harvested from the lake, sun dried, and prepared as thin green wafers called Dihé for direct consumption or to be powdered as an ingredient for a sauce, some of which are flavored, to be served on balls of cooked millet or maize (Dangeard 1940, Delpeuch et al. 1975; Ciferri 1983; GCP/ CHD/029/EC 2016). Léonard and Compère reported that consumption is mostly restricted to populations northeast of Lake Chad composed primarily of the Kanebou people (where the original sample described by Dangeard originated), but that it is not eaten by fishermen and nomadic people immediately adjacent to Lake Chad or by indigenous peoples near other lakes with abundant Arthrospira fusiformis populations (Léonard and Compère 1967, Ciferri 1983). This finding that Arthrospira fusiformis is consumed by only a minority of the population of Chad was reconfirmed by a careful survey by Delpeuch et al. (1975) who wrote:

"Consumption is limited to a small part of the Kanem population.

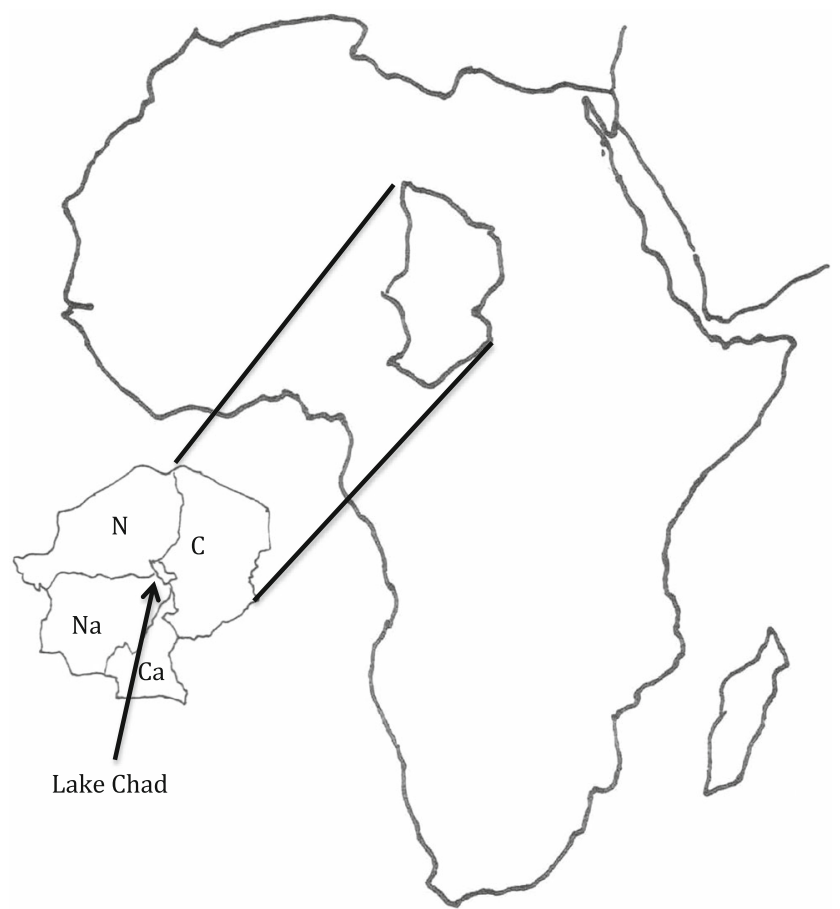

Fig. 1 Location of Lake Chad. C, Chad; N, Niger; Na, Nigeria; Ca, Cameroon
... the frequencies of use vary between one and six meals out of ten; the quantities consumed per person during meals, in the sauce accompanying the millet, are between 9 and 13 g." (Delpeuch et al. 1975, p. 497).

Arthrospira is processed on the shores of Lake Chad for sale in the market (Abulqader et al. 2000) from where we obtained our samples. The wind-blown cyanobacterial scum along the lake shore is gathered and filtered into clay vessels, and then transported to nearby dunes, where the cyanobacterial material is poured into small depressions in the sand for sun drying (Delpeuch et al. 1975). Arthrospira fusiformis from Lake Chad is claimed to offer significant nutritional benefits to the indigenous people, including as a source of $\beta$-carotene (Carcea et al. 2015, Soudy et al. 2018), and there is some indication that this particular species has antiviral properties (Sharaf et al. 2013). Since Arthrospira fusiformis from Lake Chad has been proposed for economic development (Charpy et al. 2008, CP/CHD/029/EC, 2016), a cyanotoxin analysis of market samples is needed.

The presence of Arthrospira as a common component of waters in Africa is well known, mostly from the African Rift Valley Lakes Nakuru, Bogoria and Elmenteita in Kenya and of laboratory isolates from Mozambique. A number of cyanobacterial toxins have been identified in cyanobacterial material and/or clinical materials from these sites and include microcystins, anatoxin-a and BMAA as examples (Krienitz et al. 2003; Ballot et al. 2004; Mussagy et al. 2006; Metcalf et al. 2006, 2013).

Concerning Lake Chad, no research has investigated the potential for the presence of toxins in cyanobacterial material and its potential amino acid nutritional quality. A question of particular interest is the possible presence of BMAA in Arthrospira fusiformis consumed by indigenous people in Chad (Charpy et al. 2008). BMAA is a non-protein amino acid produced by cyanobacteria (Cox et al. 2005) that contaminates traditional food items in the Pacific island of Guam (Cox et al. 2003; Banack et al. 2006; Banack and Murch 2009) and has been implicated as a cause of a fatal progressive neurodegenerative disease among the indigenous Chamorro people there (Cox et al. 2016; Davis et al. 2020). At its peak, $25 \%$ of adults in two villages in Guam perished from amyotrophic lateral sclerosis/parkinsonism dementia complex (ALS/PDC) (Cox and Sacks 2002; Cox et al. 2003). Similar patterns of progressive neurodegenerative disease have not been reported from Chad, although on average the inhabitants of Chad have twice the number of disability-adjusted lifeyears due to neurological disorders than the inhabitants of Guam (Feigin et al. 2017). Since there has not been a careful survey of ALS/PDC type-diseases in Chad, it is possible that an increased incidence of progressive neurodegenerative disease there has gone unnoticed, but it is also possible that BMAA does not contaminate dried cakes and other traditional food items in Chad made from Arthrospira, perhaps due to 
Fig. 2 Processed cyanobacterial material from Chad. a Arsa Abdoulaye nicknamed "Banaa" pours into a bucket, Arthrospira, a dietary supplement (both for human and animal nutrition), in Brandji, on Lake Chad on December 12, 2009. (Photo credit Patrick Fort/AFP via Getty Images). b Processed cyanobacterial mats. c Light microscopy of Arthrospira material. d Fluorescence microscopy of Arthrospira material. e Straight and coiled filaments of Arthrospira

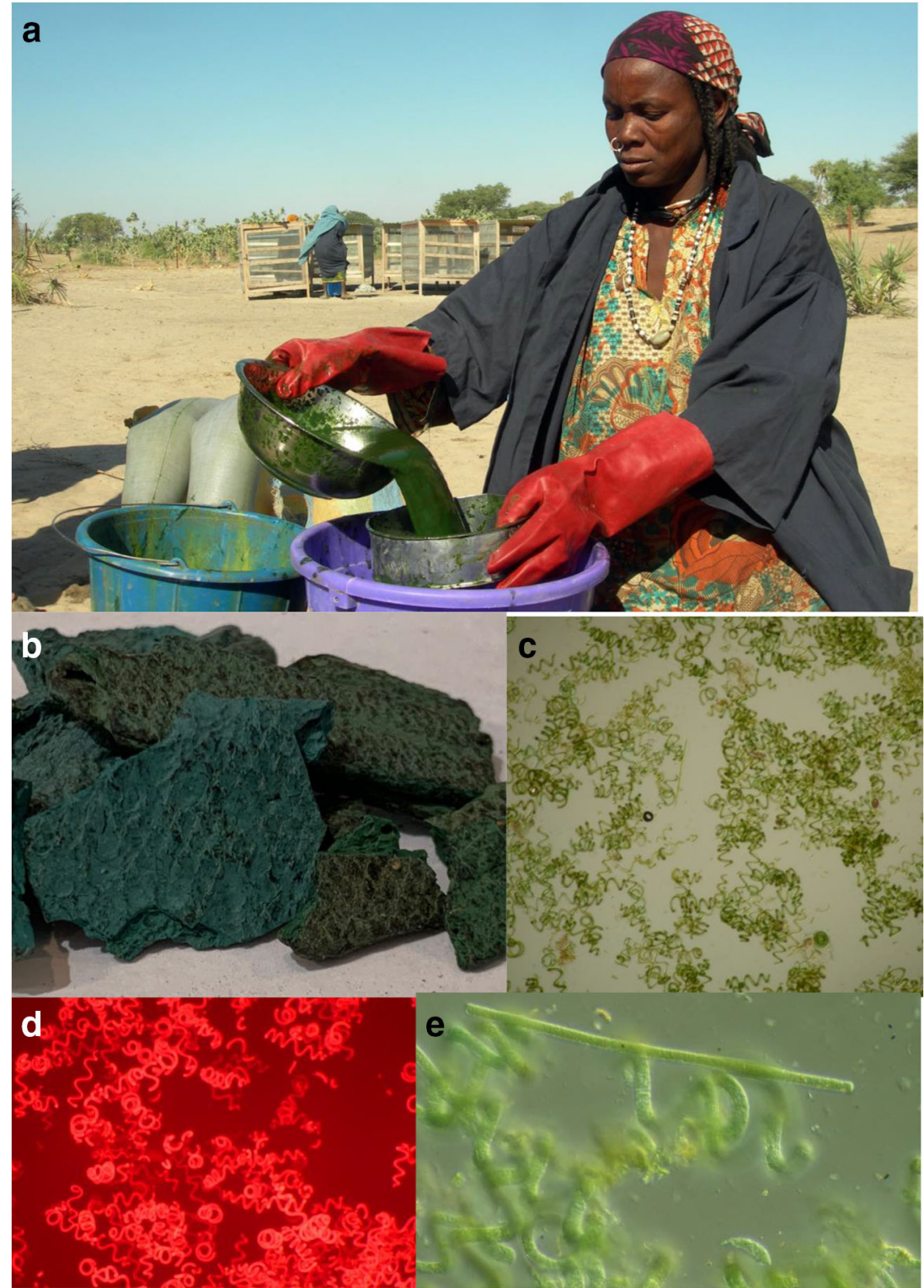

abundant nitrogen in the lake water which decreases BMAA production (Downing et al. 2011). Alternatively, there may be taxonomic differences in the Arthrospira found in Lake Chad compared to other species in this genus (Cox et al. 2005). The purpose of this study was to evaluate the cyanotoxin content of Arthrospira in Dihé consumed by the indigenous people of Chad and to quantify the amino acids in this food staple. Cyanotoxin analysis was performed using liquid chromatography, mass spectrometry, enzyme inhibition assays, and polymerase chain reaction (PCR) to provide a broader understanding of the potential for toxin production in this cyanobacterial material. Furthermore, cyanobacterial material from Lake Chad is a commonly-consumed local food that may have great nutritional value. Therefore, we wished to determine whether this indigenous food source was potentially beneficial for people who are considered in poverty and undernourished, and whether there was a risk of short and/or long-term intoxication from the presence of toxic compounds.

\section{Materials and Methods}

\section{Extraction of Cyanobacterial Material}

Dihé wafers collected and processed from cyanobacteria in Lake Chad were purchased at markets approximately 50$80 \mathrm{~km}$ distant from the lake in July and August 2017 (see Table 1 for markets). Upon receipt at the Brain Chemistry Labs (Jackson, WY), a small piece was removed and resuspended with DQ water for visual assessment of cyanobacteria by light and fluorescence microscopy using a Zeiss Axioplan 2 fluorescence microscope (Fig. 2b-e). Cyanobacteria were 
Table 1 Microscopic analysis of cyanobacterial food supplements from Chad (2017)

\begin{tabular}{lll}
\hline Sample & Location/date & Microscopy \\
\hline 1 & Koundoul \#1 08/14 & $A, d$ \\
2 & NDjaweng souk 08/12 & $A$ \\
3 & Abena \#1 08/07 & $A, d$ \\
4 & Chagoua \#1 07/25 & $A, f$ \\
5 & Dembe \#1 07/15 & $A$ \\
6 & Moursal market \#1 07/09 & $A, f$ \\
7 & Koundoul \#2 08/14 & $A, f$ \\
8 & Abena \#2 08/07 & $A, f$ \\
9 & Dembe \#2 07/15 & $A, d, D, f$ \\
10 & Chagoua \#2 07/25 & $A, f$ \\
11 & Moursal market \#2 07/09 & $A, f$ \\
12 & NDjaweng souk 08/12 & $A, D$ \\
\hline
\end{tabular}

A Arthrospira, $d$ cell debris, $f$ straight cyanobacterial filaments, $D$ diatoms

identified to generic level according to Whitton (2002) and found to be consistent with Arthrospira as previously identified by Abulqader et al. (2000). As the samples purchased from the markets were dry, no further processing was performed prior to extraction of cyanotoxins $(50 \mathrm{mg} / \mathrm{ml})$, amino acids, and DNA. For microcystins, an aliquot was weighed and extracted with $70 \%(\mathrm{v} / \mathrm{v})$ methanol with ultrasonication. Samples were left to stand at room temperature for $1 \mathrm{~h}$, before centrifugation and analysis of the supernatant. For cylindrospermopsin and anatoxin-a, subsamples of the material were weighed and extracted with either DQ water or $100 \%$ methanol. The material was ultrasonicated and allowed to stand at room temperature for $1 \mathrm{~h}$ before centrifugation. The DQ extracts were stored at $-20{ }^{\circ} \mathrm{C}$ until analyzed, and the methanol extracts were dried in a SpeedVac and stored at $20^{\circ} \mathrm{C}$. For BMAA and isomers, aliquots of the cyanobacterial material were weighed and extracted using $20 \%(\mathrm{w} / \mathrm{v})$ trichloroacetic acid (TCA) with sonication. The samples were left overnight at $4{ }^{\circ} \mathrm{C}$ and were centrifuged the following day. A subsample of the TCA extract was added to an equal volume of $12 \mathrm{M} \mathrm{HCl}$ for digestion at $110{ }^{\circ} \mathrm{C}$ for $16 \mathrm{~h}$. The pelleted material was resuspended with $6 \mathrm{M} \mathrm{HCl}$ and underwent digestion at $110^{\circ} \mathrm{C}$ for $16 \mathrm{~h}$. The TCA and $\mathrm{HCl}$ extracts were centrifuge filtered $(0.2 \mu \mathrm{m})$ and dried in a SpeedVac and stored at $-20{ }^{\circ} \mathrm{C}$ until analysis. For amino acid extraction, aliquots of the material were weighed and hydrolyzed with $6 \mathrm{M} \mathrm{HCl}$ for $16 \mathrm{~h}$ at $110^{\circ} \mathrm{C}$. Aliquots were centrifuge filtered, dried in a SpeedVac, and stored dry at $-20{ }^{\circ} \mathrm{C}$ until analysis.

\section{RT-PCR}

Crust samples were weighed into $1.5 \mathrm{~mL}$ PCR-clean Eppendorf tubes, the weights recorded, then $500 \mu \mathrm{L}$ of lysis buffer (100 mM Tris HCl, 5 mM EDTA, 0.2\% SDS, $200 \mathrm{mM}$ $\mathrm{NaCl}$, pH 9.0) was added to each tube. Proteinase $\mathrm{K}$ was added to each tube at a final concentration of $1 \mu \mathrm{g} / \mathrm{mL}$ (from stock of $100 \mu \mathrm{g} / \mathrm{mL}$ ), and samples were incubated at $55^{\circ} \mathrm{C}$ for $1 \mathrm{~h}$ with gentle shaking. Following incubation, samples were centrifuged ( $5 \mathrm{~min}, 10,000 \times g$, RT), the supernatant transferred to a new tube and $500 \mu \mathrm{L}$ phenol/chloroform/isoamyl alcohol added. Tubes were vortexed, then centrifuged $(5 \mathrm{~min}$, $10,000 \times g, \mathrm{RT})$, and the aqueous layer was transferred to a fresh tube, $500 \mu \mathrm{L}$ chloroform was added, and tubes mixed by inverting several times. Tubes were centrifuged again (5 min, $10,000 \times g, \mathrm{RT}$ ) and the supernatant transferred to a fresh tube. Twenty five microliters of $5 \mathrm{M} \mathrm{NaCl}$ was added to the supernatant, the tubes mixed by inversion, then $1 \mathrm{~mL}$ of 95\% ethanol was added, and mixed well. Tubes were incubated at $-20{ }^{\circ} \mathrm{C}$ overnight to allow the DNA to precipitate. Following ethanol precipitation, the tubes were centrifuged ( $5 \mathrm{~min}, 10,000 \times \mathrm{g}, \mathrm{RT}$ ), the supernatant was removed and the pellets allowed to air-dry for 20-30 min. Once all the ethanol had evaporated, the pellets were resuspended in nuclease-free water and the DNA concentration measured on a NanoDrop ${ }^{\text {TM }} 2000$ Spectrophotometer (Thermo Fisher Scientific).

Custom primers for $m c y \mathrm{D}$ (microcystin synthetase) were synthesized by Sigma-Aldrich Custom Oligos for two amplicons, $818 \mathrm{bp}$; forward $\left(5^{\prime}-3^{\prime}\right)$, GATCCGATTGAATT AGAAAG and reverse $\left(5^{\prime}-3^{\prime}\right)$, GTATTCCCCAAGAT TGCC (Rantala et al. 2004) and 297 bp; forward 5'-GGTT CGCCTGGTCAAAGTAA-3' and reverse, 5'-CCTC GCTAAAGAAGGGTTGA-3' (Kaebernick et al. 2000). RT PCR was conducted using the HotStarTaq ${ }^{\circledR}$ DNA polymerase kit (QIAGEN, Cat No./ID: 203203) using 50 ng DNA and in accordance with the manufacturer's instructions using the following conditions; initial denaturation for $15 \mathrm{~min}, 95^{\circ} \mathrm{C}$; then 35 cycles of $30 \mathrm{~s}, 94^{\circ} \mathrm{C} ; 30 \mathrm{~s},\left(56^{\circ} \mathrm{C}, 818 \mathrm{bp}\right.$ amplicon, $60^{\circ} \mathrm{C}$, $297 \mathrm{bp}$ amplicon), $1 \mathrm{~min}, 72^{\circ} \mathrm{C}$, and final extension for $10 \mathrm{~min}$ at $72{ }^{\circ} \mathrm{C}$. The PCR product $(1 \mu \mathrm{L})$ was run on a $2 \%$ agarose gel in $1 \times$ TAE with $2.5 \%$ GelStar $^{\mathrm{TM}}$ Nucleic Acid Gel Stain (Lonza Bioscience, Cat No./ID: 50535) for approximately 45 min or until the dye front reached the bottom of the gel. The gel was imaged on a BioRad ChemiDoc in the UV channel. A positive control for $m c y \mathrm{D}$, Microcystis PCC7813 (Pasteur Culture Collection, Paris, France), was simultaneously extracted, transcribed (10 ng), and run in the gel, as described above. Conditions were optimized using a temperature gradient during the reverse transcription and DNA concentrations from 1 to $500 \mathrm{ng}$.

\section{UPLC-PDA}

Dried extracts were resuspended in their respective solvent for ultra-performance liquid chromatography with photodiode array (UPLC-PDA) analysis of known cyanotoxins using a 
Waters Acquity UPLC system (Metcalf et al. 2018). Microcystins (70\% v/v methanol), cylindrospermopsin (DQ water), and anatoxin-a (DQ water) were assessed by comparison to known MC-LR, cylindrospermopsin, and anatoxin-a standards with PDA spectral matching at $238 \mathrm{~nm}, 262 \mathrm{~nm}$, and $227 \mathrm{~nm}$, respectively.

\section{Triple-Quadrupole Mass Spectrometry}

Dried free and protein bound samples were resuspended with DQ water and derivatized with 6-aminoquinolyl-Nhydroxysuccinimidyl carbamate (AQC) for triple-quadrupole mass spectrometry (Metcalf et al. 2018; Banack 2020). Further samples underwent solid-phase extraction (SPE; Metcalf et al. 2013) to concentrate samples and remove contaminating compounds. After elution, the samples were dried in a rotary evaporator and resuspended with $500 \mu \mathrm{l} 20 \mathrm{mM}$ $\mathrm{HCl}$. These were again derivatized with $\mathrm{AQC}$ and underwent triple-quadrupole mass spectrometry for BMAA and isomers using the validated AOAC method with slight modifications for optimization in a different laboratory (Glover et al. 2015; Banack 2020). LOD was calculated at $0.01 \mathrm{ng} / \mathrm{ml}$, and LLOQ was calculated to be $0.04 \mathrm{ng} / \mathrm{ml}$ for all analytes using FDA guidelines (FDA 2018).

\section{Acetylcholine Esterase Inhibition Assay}

Aqueous extracts of cyanobacterial material underwent preliminary assessment of anatoxin-a $(S)$ content using a colorimetric acetylcholine esterase inhibition assay with reference to a neostigmine standard curve (Metcalf et al. 2018).

\section{Amino Acid Analysis of Cyanobacterial Material}

The dried total acid hydrolysate aliquot $(100 \mu \mathrm{l})$ was resuspended to the original volume with $20 \mathrm{mM} \mathrm{HCl}$ and then diluted $1 / 10$ with $20 \mathrm{mM} \mathrm{HCl}$ for amino acid analysis using a Hitachi L-9800 amino acid analyzer using a PH buffer set (PH-1/AN0-8706; PH-2/AN0-8707; PH-3/AN0-8708; PH-4/ AN0-8709; PH-RG/AN0-8710) and column (L8900PH8554514) following a method according to Cox and Metcalf (2017). Amino acids were quantified with reference to standards of the 20 canonical amino acids.

\section{Results}

Light microscopy of the Chad cyanobacterial material showed the presence of Arthrospira as the principal cyanobacterium to be present (Table 1; Fig. 2b-d). Analysis of the cyanobacterial material by UPLC-PDA did not identify cylindrospermopsin or anatoxin-a, with trace amounts of anatoxin-a $(S)$ in four samples according to acetylcholine esterase inhibition assay (Table 2). Analysis by UPLC-PDA indicated the presence of microcystin variants at up to $20 \mu \mathrm{g} / \mathrm{g}$ in six samples, which were not identified further due to their low concentration. Analysis by PCR for microcystin synthetase did not detect genes for $m c y \mathrm{D}$. When the extracts were analyzed for BMAA and isomers, no BMAA or AEG were detected. However, DAB was present as both a free and bound compound. Furthermore, when the free TCA extract was hydrolyzed, the amount of DAB detected was found to greatly increase, suggesting that DAB may be present as a bound component of small peptides or other compounds (Table 2).
Table 2 Cyanotoxin analysis of cyanobacterial food supplements from Chad (2017). All values expressed as $\mu \mathrm{g} / \mathrm{g}$

\begin{tabular}{llllll}
\hline Sample & Anatoxin-a(S) & Microcystin & Free DAB & Hydrolysed free DAB & Bound DAB \\
\hline 1 & T & ND & 0.89 & 72.05 & 2.16 \\
2 & ND & $19.6(3)$ & 0.17 & 3.60 & 1.59 \\
3 & ND & ND & 1.16 & 64.15 & 5.02 \\
4 & ND & ND & 1.50 & 18.34 & 2.54 \\
5 & ND & ND & 0.20 & 6.10 & 1.59 \\
6 & T & ND & 1.14 & 15.93 & 1.80 \\
7 & ND & 1.48 & 2.21 & 28.89 & 1.32 \\
8 & ND & 1.59 & 1.15 & 21.53 & 1.08 \\
9 & T & 1.28 & 0.81 & 19.73 & 1.15 \\
10 & ND & 0.49 & 2.24 & 36.24 & 1.38 \\
11 & T & 4.72 & 1.33 & 31.64 & 1.29 \\
12 & ND & ND & ND & 13.87 & 0.82 \\
\hline
\end{tabular}

Numbers in parentheses represent no. variants

$T$ trace, $N D$ not detected 
Amino acid analysis showed the presence of the majority of the 20 canonical amino acids in the cyanobacterial material, ranging from not detectable to around $50 \mu \mathrm{g} / \mathrm{mg}$ for glutamate (Table 3). The order of abundance of amino acids was Glu $>$ Tyr $>$ Trp $>$ Asp $>$ Ala $>$ Arg $>$ Val $>$ Thr $>$ Gly $>$ Leu $>$ Ser $>$ Ly$\mathrm{s}>$ Pro $>$ Phe $>$ His $>$ Cys $>$ Met $>$ Ile $>$ Gln $>$ Asn .

\section{Discussion}

In this study, we obtained cyanobacterial material from Lake Chad that is used as a human food source and is sold through local markets. Using a variety of analytical techniques, we assessed this material for known cyanotoxins and nutritional (amino acid) content, finding it to have generally low cyanotoxin content and to be rich in amino acids.

Cyanobacterial "health food" supplements have increased in popularity (Bishop and Zubeck 2012), and with the potential to contain harmful toxins, Spirulina (including Arthrospira) and Aphanizomenon have been extensively studied (e.g., Roy-LaChapelle et al. 2017). Examination of such foodstuffs has identified the presence of microcystins, anatoxin-a and BMAA as examples (Rawn et al. 2007; Rellan et al. 2009; Glover et al. 2015; Roy-LaChappelle et al. 2017). Although anatoxin-a and derivatives were not found when assessing cyanobacterial supplements in the study of Rawn et al. (2007), a study by Rellan et al. (2009) confirmed their presence in $7.7 \%$ of supplements. A further study of 18 cyanobacterial supplements determined that 8 contained some amount of a range of cyanobacterial toxins (RoyLaChapelle et al. 2017), including 5 that contained anatoxina and/or derivatives of this neurotoxic alkaloid. Furthermore, their assessment of microcystins in cyanobacterial supplements showed 7 of these Spirulina or Aphanizomenon supplements contained microcystins, with up to 4 individual microcystin variants found (Roy-LaChapelle et al., 2017). Of the strains tested, BMAA was found in two strains of Aphanizomenon and not in Spirulina (Roy-LaChapelle et al. 2017). Conversely, in the study of Glover et al. (2015), 5 bulk powders comprised of Spirulina were assessed for BMAA and isomers. The isomers $N$-(2-aminoethyl)glycine (AEG) and 2,4-diaminobutyric acid (DAB) were identified in all

Table 3 Amino acid analysis of cyanobacterial food supplements from Chad. Values are expressed as $\mu \mathrm{g} / \mathrm{mg}$ dry weight. Figures in parentheses show the recommended daily intake of essential amino acids for adults (mg/kg; WHO, 2007)

\begin{tabular}{|c|c|c|c|c|c|c|c|c|c|c|c|c|c|c|}
\hline \multirow[b]{2}{*}{ Amino acid } & \multicolumn{12}{|c|}{ Chad supplement } & \multirow[b]{2}{*}{ Mean } & \multirow[b]{2}{*}{ Rank } \\
\hline & 1 & 2 & 3 & 4 & 5 & 6 & 7 & 8 & 9 & 10 & 11 & 12 & & \\
\hline Asp & 26.2 & 25.7 & 25.2 & 19.6 & 23.6 & 19.6 & 22.4 & 25.0 & 20.0 & 23.4 & 21.7 & 23.6 & 23.0 & 4 \\
\hline Thr & 15.9 & 16.2 & 15.6 & 12.1 & 14.4 & 12.3 & 13.1 & 14.5 & 12.1 & 13.8 & 13.2 & 14.2 & 14.0 & 8 \\
\hline Ser & 1.5 & 15.9 & 14.3 & 11.1 & 13.3 & 10.7 & 12.5 & 14.1 & 10.4 & 13.2 & 11.6 & 13.5 & 11.8 & 11 \\
\hline Asn & ND & ND & ND & ND & ND & ND & ND & ND & ND & ND & ND & ND & ND & 20 \\
\hline Glu & 49.1 & 51.6 & 46.7 & 41.0 & 19.2 & 40.4 & 47.3 & 53.3 & 39.8 & 49.0 & 43.8 & 46.0 & 43.9 & 1 \\
\hline Gln & ND & 0.2 & 0.3 & ND & 0.3 & 0.3 & 0.4 & 0.5 & 0.4 & 0.5 & 0.5 & 0.3 & 0.4 & 19 \\
\hline Cys $(4.1)^{*}$ & 2.6 & 0.4 & 5.5 & 2.8 & 5.0 & 5.0 & 3.1 & 2.7 & 9.0 & 3.3 & 9.0 & 1.5 & 4.2 & 16 \\
\hline Pro & 5.8 & 1.4 & 6.4 & 12.6 & 6.7 & 16.3 & 8.0 & 6.0 & 21.3 & 8.7 & 18.4 & 5.0 & 9.7 & 13 \\
\hline Gly & 14.8 & 15.1 & 14.6 & 11.0 & 13.2 & 11.0 & 12.2 & 13.5 & 11.0 & 12.7 & 12.0 & 13.3 & 12.9 & 9 \\
\hline Ala & 25.5 & 23.6 & 23.8 & 17.9 & 21.8 & 17.2 & 19.2 & 21.3 & 17.3 & 20.4 & 19.1 & 21.1 & 20.7 & 5 \\
\hline Val & 17.9 & 18.4 & 17.6 & 13.5 & 16.2 & 13.7 & 14.9 & 16.9 & 14.0 & 16.1 & 15.3 & 16.3 & 15.9 & 7 \\
\hline $\operatorname{Met}(10.4)^{*}$ & 2.9 & 4.1 & 4.0 & 3.1 & 3.1 & 3.4 & 2.7 & 2.5 & 1.7 & 2.8 & 2.4 & 2.4 & 2.9 & 17 \\
\hline Ile (20) & 0.8 & 0.2 & 0.8 & 0.4 & 0.7 & 0.3 & 0.5 & 0.5 & 0.4 & 0.5 & 0.5 & 0.6 & 0.5 & 18 \\
\hline Leu (39) & 14.3 & 13.8 & 14.3 & 10.8 & 13.5 & 11.0 & 12.1 & 13.5 & 11.6 & 12.8 & 12.3 & 12.8 & 12.7 & 10 \\
\hline $\operatorname{Tyr}(25)^{+}$ & 41.6 & 41.6 & 41.4 & 31.1 & 38.4 & 31.4 & 34.5 & 38.3 & 32.1 & 36.3 & 34.7 & 37.1 & 36.5 & 2 \\
\hline Phe $(25)^{+}$ & 10.5 & 9.0 & 9.8 & 7.2 & 9.1 & 6.9 & 8.2 & 9.1 & 7.7 & 8.7 & 8.2 & 9.1 & 8.6 & 14 \\
\hline $\operatorname{Trp}$ & 34.8 & 34.0 & 33.9 & 25.3 & 31.3 & 25.9 & 28.1 & 30.8 & 26.2 & 29.5 & 28.3 & 29.2 & 29.8 & 3 \\
\hline Lys (30) & 13.9 & 13.4 & 13.5 & 9.9 & 12.2 & 9.8 & 11.1 & 12.4 & 10.3 & 11.9 & 11.2 & 11.3 & 11.7 & 12 \\
\hline His (10) & 3.4 & 7.6 & 7.4 & 5.6 & 7.1 & 5.3 & 6.7 & 7.9 & 6.8 & 7.4 & 6.9 & 7.5 & 6.6 & 15 \\
\hline $\operatorname{Arg}$ & 21.6 & 19.8 & 20.6 & 13.0 & 19.2 & 15.6 & 18.6 & 20.9 & 7.9 & 19.7 & 9.3 & 19.3 & 17.1 & 6 \\
\hline
\end{tabular}

Rank, highest to lowest

$N D$ not detected

*Combined recommendation

${ }^{+}$Combined recommendation (25 total) 
samples tested, and BMAA was also identified in 4 out of 5 samples at up to $0.74 \mu \mathrm{g} / \mathrm{g}$ (Glover et al. 2015).

We did not detect BMAA in Arthrospira fusiformis processed as Dihé wafers from Lake Chad. Although a variety of analytical methods are available for the detection of BMAA, only one has been approved by the AOAC and demonstrated to be a robust method among laboratories (Glover et al. 2015; Banack 2020). The stability and validity of using methods which do not derivatise BMAA (e.g. HILIC) have also been brought into question (Tymm et al. 2020). Therefore, although we did not detect BMAA in Arthrospira from Chad, this is consistent with the findings of Roy-LaChappelle et al. (2017) and used the same analytical method as that employed by the study of Glover et al. (2015).

We did find chromatographic peaks consistent with microcystins in the Dihé wafers, but did not detect microcystin synthetase genes using PCR in this material, although the indigenous processing of the material may have degraded the DNA, which is considered to be less stable than microcystins in dried cyanobacteria (Metcalf et al. 2012). We found four samples with trace amounts of anatoxin-a $(S)$, which is a potent neurotoxin, and five samples with microcystin concentrations up to $20 \mu \mathrm{g} / \mathrm{g}$, exceeding that which is considered safe for human consumption in supplements $(<1 \mu \mathrm{g} / \mathrm{g}$, Marsan et al. 2017). The potential adverse health effects of DAB in the human diet have yet to be fully elucidated, but this diamino acid has been demonstrated in cyanobacterial foodstuffs (e.g., Glover et al. 2015). BMAA is also a potential cause for concern as chronic exposure to this neurotoxin is thought to be a trigger for neurodegenerative disease (Cox et al. 2016; Davis et al. 2020). The unique character of Lake Chad may account for the lack of BMAA detection reported here or may be the result of the low number of samples tested and the potential variability in concentration, as nitrogen can affect BMAA production in Synechocystis (Downing et al. 2011). Therefore, lakes with high nitrogen content may support cyanobacteria with BMAA at concentrations, which are low or undetectable. However, in the event of seasonal drying (Lemoalle et al. 2012), changing agricultural practices, or climate change (Coe and Foley 2001), there may still be the potential for endemic cyanobacteria to produce BMAA and future monitoring should be carried out on Lake Chad to ensure that food products from these waters are suitable for human consumption. In addition to BMAA and isomers, microcystins, and anatoxin-a(S), further research should examine the potential production of anatoxin-a by this genus as previous research has shown that microcystins and anatoxin-a are present in Arthrospira from African Rift Valley lakes, such as Lakes Nakuru and Bogoria, associated with periodic mass mortalities of Lesser Flamingo (Krienitz et al. 2003).

Amino acid analysis of the Lake Chad material indicates that this cyanobacterium is a rich source of amino acids and may help supplement the local population who are generally undernourished and poor (World Food Programme 2019). The absence of glutamine and asparagine in the analysis of this cyanobacterial material may have been due to degradation during acid hydrolysis. Although there is the potential for the production of toxins in Lake Chad cyanobacteria, Spirulina and Arthrospira have been shown to be good sources of protein (Becker 2007) and lipids (Bishop and Zubeck 2012). Furthermore, Spirulina may also be a good source of vitamins (B, E) and may help in treating diseases such as high blood pressure (Iwata et al. 1990) and diabetes (Takai et al. 1991) and as part of a balanced diet could provide essential amino acids and proteins. Assessment of commercially available Spirulina platensis samples showed that they could contribute significantly to amino acid RDI values from $12.8 \%$ (Lys) to $38.8 \%$ (Thr) and provide a significant input (74\%) of sulfur amino acids (Misurcová et al. 2014). It would also be useful to understand why some indigenous peoples living adjacent to Lake Chad do not consume the cyanobacterial material, and if there is any seasonality to the collection and processing of the cyanobacterial blooms that are then sold to those indigenous people who do consume the material. Such seasonality could determine whether there is the potential for accumulation of cyanobacterial toxins and provide guidance for collection, processing and consumption. Observations concerning a lack of consumption from different investigators (e.g. Léonard and Compère 1967; Delpeuch et al. 1975) raise an important question: why is there no commerce among human populations immediately adjacent to Lake Chad in Arthrospira fusiformis or the dried Dihé cakes formed from it, whereas it is found commercially in markets elsewhere in Chad? It is possible that there may be cultural prescriptions against consumption of Dihé by those who live next to the source, possibly due to the potential presence of toxins. Only careful ethnographic studies can resolve this question, which although interesting, is beyond the scope of this study.

Studies examining the nutrition of indigenous people and their health would be useful in understanding whether cyanobacterial supplementation to the diet may be beneficial. Due to the geopolitical nature of Chad, consumption of cyanobacteria, if carefully monitored for the absence of toxins, may act as a significant health benefit and economic crop for the local population.

Acknowledgments We thank Abino Goursam for collections of Dihé from markets around Lake Chad and Professor Geoffrey A. Codd for the generous gift of freeze-dried PCC7813. We also thank the William Stamps Farrish Fund for supporting the purchase of the triple-quadrupole mass spectrometer.

\section{Compliance with Ethical Standards}

Conflict of Interest The authors declare that they have no conflict of interest.

Open Access This article is licensed under a Creative Commons Attribution 4.0 International License, which permits use, sharing, 
adaptation, distribution and reproduction in any medium or format, as long as you give appropriate credit to the original author(s) and the source, provide a link to the Creative Commons licence, and indicate if changes were made. The images or other third party material in this article are included in the article's Creative Commons licence, unless indicated otherwise in a credit line to the material. If material is not included in the article's Creative Commons licence and your intended use is not permitted by statutory regulation or exceeds the permitted use, you will need to obtain permission directly from the copyright holder. To view a copy of this licence, visit http://creativecommons.org/licenses/by/4.0/.

\section{References}

Abulqader G, Barsanti L, Tredici MR (2000) Harvest of Arthrospira platensis from Lake Kossorom (Chad) and its household usage among the Kanembu. J Appl Phycol 12:493-498

Ballot A, Krienitz L, Kotut K, Wiegand C, Metcalf JS, Codd GA, Pflugmacher S (2004) Cyanobacteria and cyanobacterial toxins in three alkaline Rift Valley lakes of Kenya- Lakes Bogoria, Nakuru and Elmenteita. J Plankton Res 26:925-935

Banack SA (2020) Second laboratory validation of $\beta-N$-methylamino-Lalanine, $N$-(2-aminoethyl)glycine, and 2,4-diaminobutyric acid by ultra-performance liquid chromatography and tandem mass spectrometry. Neurotox Res. https://doi.org/10.1007/s12640-02000208-x

Banack SA, Murch SJ (2009) Multiple neurotoxic items in the Chamorro diet link BMAA with ALS/PDC. Amyotrophic Lateral Sclerosis 10(sup2):34-40

Banack SA, Murch SJ, Cox PA (2006) Neurotoxic flying foxes as dietary items for the Chamorro people, Marianas Islands. J Ethnopharmacol 106(1):97-104

Becker EW (2007) Micro-algae as a source of protein. Biotechnol Adv 25:207-210

Bishop WM, Zubeck HM (2012) Evaluation of microalgae for use as nutraceuticals and nutritional supplements. J Nutr Food Sci 2:5. https://doi.org/10.4712/2155-9600.1000147

Carcea M, Sorto M, Batello C, Narducci V, Aguzzi A, Azzini E, Fantauzzi P, Finotti E, Gabrielli P, Galli V, Gambelli L, Maintha KM, Namba F, Ruggeri S, Turfani V (2015) Nutritional characterization of traditional and improved dihé, alimentary blue-green algae from the Lake Chad region in Africa. LWT-Food Science and Technology 62(1):753-763

Charpy L, Langlade MJ, Alliod R (2008) La Spiruline peut-elle être un atout pour la santé et le développement en Afrique. Rapport d'expertise pour le Ministère de l'Agriculture et de la Pêche, $49 \mathrm{pp}$

Ciferri O (1983) Spirulina, the edible microorganism. Microb Rev 47: $551-578$

Coe MT, Foley JA (2001) Human and natural impacts on the water resources of the Lake Chad basin. J Geograph Res 106:3349-3356

Cox PA, Banack SA, Murch SJ (2003) Biomagnification of cyanobacterial neurotoxins and neurodegenerative disease among the Chamorro people of Guam. Proc Natl Acad Sci 100(23): 13380-13383

Cox PA, Banack SA, Murch SJ, Rasmussen U, Tien G, Bidigare RR, Metcalf JS, Morrison LF, Codd GA, Bergman B (2005) Diverse taxa of cyanobacteria produce $\beta-\mathrm{N}$-methylamino-L-alanine, a neurotoxic amino acid. Proc Natl Acad Sci 102(14):5074-5078

Cox PA, Davis DA, Mash DC, Metcalf JS, Banack SA (2016) Dietary exposure to an environmental toxin triggers neurofibrillary tangles and amyloid deposits in the brain. Proc Royal Soc B 283(1823): 20152397
Cox PA, Metcalf JS (2017) Traditional food items in Ogimi, Okinawa: Lserine content and the potential for neuroprotection. Curr Nutrition Rep 6(1):24-31

Cox PA, Sacks OW (2002) Cycad neurotoxins, consumption of flying foxes, and ALS-PDC disease in Guam. Neurology 58(6):956-959

Dangeard P (1940) Sur une algue bleue alimentaire pour l'homme: Arthrospira platensis (Nordst.) Gomont. Actes Soc Linn Bordeaux Extr Proces-verbaux 91:39-41

Davis DA, Cox PA, Banack SA, Lecusay PD, Garamszegi SP, Hagan MJ, Powell JT, Metcalf JS, Palmour RM, Beierschmitt A, Bradley WG (2020) L-serine reduces spinal cord pathology in a vervet model of preclinical ALS/MND. J Neuropath \& Exper Neurology 79(4): 393-406

Delpeuch F, Joseph A, Cavelier C (1975) Consumption and nutritional contribution of the blue algae (Oscillatoria platensis) among some populations of Kanem (Tchad). Annales de la nutrition et de l'alimentation 29(6):497-516

Downing S, Banack SA, Metcalf JS, Cox PA, Downing TG (2011) Nitrogen starvation of cyanobacteria results in the production of $\beta$ - $N$-methylamino-L-alanine. Toxicon 58:187-194

FDA (2018) Bioanalytical method validation. Guidance for industry. U.S. department of health and human services, food and drug administration, center for drug evaluation and research, center for veterinary medicine. Biopharmaceutics, Washington, DC, May 2018

Feigin VL, Abajobir AA, Abate KH, Abd-Allah F, Abdulle AM, Abera SF, Abyu GY, Ahmed MB, Aichour AN, Aichour I, Aichour MTE (2017) Global, regional, and national burden of neurological disorders during 1990-2015: a systematic analysis for the Global Burden of Disease Study 2015. Lancet Neurol 16(11):877-897

GCP/CHD/029/EC: Projet pilote de développement de la filière « Dihé » au Tchad. Le développement de la filière spiruline ou « dihé » au service de la population et des personnes vulnérables au Tchad. (2016) FAO

Gene SM, Shahmohamadloo RS, Ortiz X, Prosser RS (2019) Effect of Microcystis aeruginosa-associated microcystin-LR on the survival of two life stages of freshwater mussel (Lampsilis siliquoidea). Environ Toxicol Chem 38:2137-2144

Glover WB, Baker TC, Murch SJ, Brown PN (2015) Determination of $\beta$ $\mathrm{N}$-methylamino-L-alanine, $\mathrm{N}$-(2-aminoethyl)glycine, and 2,4diaminobutyric acid in food products containing cyanobacteria by ultra-performance liquid chromatography and tandem mass spectrometry: single laboratory validation. J AOAC Int 98(6):15591565

Heussner AH, Mazija L, Fastner J, Dietrich DR (2012 Dec 1) Toxin content and cytotoxicity of algal dietary supplements. Toxicol Appl Pharmacol 265(2):263-271

Huisman J, Codd GA, Paerl HW, Ibelings BW, Verspagen JM, Visser PM (2018) Cyanobacterial blooms. Nat Rev Microbiol 16:471-483

Iwata K, Inayama T, Kato T (1990) Effects of Spirulina platensis on plasma lipoprotein lipase activity in fructose-induced hyperlipidemic rats. J Nutr Sci Vitaminol 36:165-171

Janssen EML (2019) Cyanobacterial peptides beyond microcystins- a review on co-occurrence, toxicity and challenges for risk assessment. Water Res 151:488-499

Kaebernick M, Neilan BA, Börner T, Dittmann E (2000) Light and the transcriptional response of the microcystin biosynthesis gene cluster. Appl Env Microbiol 66(8):3387-3392

Komárek, J., Lund, J.W.G. (1990). What is "Spirulina platensis" in fact? Arch Hydrobiol Suppl 85 Algol Stud 58:1-6

Krienitz L, Ballot A, Kotut K, Wiegand C, Pütz S, Metcalf JS, Codd GA, Pflugmacher S (2003) Contribution of hot spring cyanobacteria to the mysterious deaths of Lesser Flamingos at Lake Bogoria, Kenya. FEMS Microbiol Ecol 43:141-148

Lemoalle J, Bader J-C, Leblanc M, Sedick A (2012) Recent changes in Lake Chad: observations, simulations and management options (1973-2011). Glob Planet Chang 80-81:247-254 
Léonard J, Compère $\mathrm{P}$ (1967) Spirulina platensis, algue bleue de grande valeur alimentaire par sa richesse en proteine. Bull Jard Bot Nat Belg 37(suppl):1-23

Marsan DW, Conrad SM, Stutts WL, Parker CH, Deeds JR (2017) Evaluation of microcystin contamination in blue-green algae dietary supplements using a protein phosphatase inhibition-based test kit. Heliyon 4:e00573. https://doi.org/10.1016/j.heliyon.2018.e00573

Mello FD, Braidy N, Marçal H, Guillemin G, Nabavi SM, Neilan BA (2018) Mechanisms and effects posed by neurotoxic products of cyanobacteria/microbial eukaryotes/dinoflagellates in algae blooms: a review. Neurotox Res 33:153-167

Metcalf JS, Codd GA (2012) Cyanotoxins. In: Whitton BA (ed) Ecology of cyanobacteria II: their diversity in space and time. Springer Science Business Media B.V.:651-676. https://doi.org/10.1007/ 978-94-007-3855 3224

Metcalf JS, Morrison LF, Krienitz L, Ballot A, Krause E, Kotut K, Putz S, Wiegand C, Pflugmacher S, Codd GA (2006) Analysis of the cyanotoxins anatoxin-a and microcystins in lesser flamingo feathers. Toxicol Environ Chem 88:159-167

Metcalf JS, Beattie KA, Purdie EL, Bryant JA, Irvine LM, Codd GA (2012) Analysis of microcystins and microcystin genes in 60-170year old dried herbarium specimens of cyanobacteria. Harmful Alg $15: 47-52$

Metcalf JS, Banack SA, Kotut K, Krienitz L, Codd GA (2013) Amino acid neurotoxins in feathers of the lesser flamingo, Phoeniconaias minor. Chemosphere 90(2):835-839. https://doi.org/10.1016/j. chemosphere.2012.09.094

Metcalf JS, Banack SA, Powell JT, Tymm FJM, Murch SJ, Brand LE, Cox PA (2018) Public health responses to toxic cyanobacterial blooms: perspectives from the 2016 Florida event. Water Policy 20:919-932

Misurcová L, Bunka F, Várva J, Ambrozová JV, Machu L, Samek D, Krácmar S (2014) Amino acid composition of algal products and its contribution to RDI. Food Chem 151:120-125

Mussagy A, Annadotter H, Cronberg G (2006) An experimental study of toxin production in Arthrospira fusiformis (Cyanophyceae) isolated from African waters. Toxicon 48:1027-1034

Paerl HW, Gardner WS, Havens KE, Joyner AR, McCarthy MJ, Newell SE, Qin B, Scott JT (2016) Mitigating cyanobacterial harmful algal blooms in aquatic ecosystems impacted by climate change and anthropogenic nutrients. Harmful Alg 54:213-222

Rantala A, Fewer DP, Hisbergues M, Rouhiainen L, Vaitomaa J, Börner T, Sivonen K (2004) Phylogenetic evidence for the early evolution of microcystin synthesis. Proc Natl Acad Sci U S A 101(2):568-573

Rawn DFK, Niedzwiadek B, Lau BP-Y, Saker M (2007) Anatoxin-a and its metabolites in blue-green algae food supplements from Canada and Portugal. J Food Protec 70(3):776-779

Rellán S, Osswald J, Saker M, Gago-Matinez A, Vasconcelos V (2009) First detection of anatoxin-a in human and animal dietary supplements containing cyanobacteria. Food Chem Toxicol 47(9):21892195
Roy-LaChapelle A, Solliec M, Bouchard MF, Sauvé S (2017) Detection of cyanotoxins in algae dietary supplements. Toxins 9:76. https:// doi.org/10.3390/toxins 9030076

Shahmohamadloo RS, Poirier DG, Almirall XO, Bhavsar SP, Sibley PK (2020) Assessing the toxicity of cell-bound microcystins on freshwater pelagic and benthic invertebrates. Ecotoxicol Environ Saf 188:109945

Sharaf M, Amara A, Aboul-Enein A, Helmi S, Ballot A, Schnitzler P (2013) Antiherpetic efficacy of aqueous extracts of the cyanobacterium Arthrospira fusiformis from Chad. Die Pharmazie-An International Journal of Pharmaceutical Sciences 68(5):376-380

Sili C, Torzillo G, Vonshak A (2012) Arthrospira (Spirulina). In: Whitton BA (ed) Ecology of cyanobacteria II: their diversity in space and time. Springer Science Business Media B.V.:677-705. https://doi. org/10.1007/978-94-007-3855_3224

Smith VH, Tilman GD, Nekola JC (1999) Eutrophication: impacts of excess nutrient inputs on freshwater, marine, and terrestrial ecosystems. Env Poll 100:179-196

Soudy ID, Minet-Quinard R, Mahamat AD, Ngoua HF, Izzedine AA, Tidjani A, Bum EN, Lambert C, Pereira B, Desjeux JF, Sapin V (2018) Vitamin A status in healthy women eating traditionally prepared Arthrospira (Dihé) in the Chad Lake area. PLoS One 13(1): p.e0191887

Stal LJ (2007) Cyanobacteria: diversity and versatility, clues to life in extreme environments. In: Seckbach J (ed) Algae and cyanobacteria in extreme environments. Springer, Dordrecht, pp 659-680

Sun H, Lü K, Minter EJ, Chen Y, Yang Z, Montagnes DJ (2012) Combined effects of ammonia and microcystin on survival, growth, antioxidant responses, and lipid peroxidation of bighead carp Hypophthalmythys nobilis larvae. J Hazardous Materials 221-222: 213-219

Takai Y, Hosoyamada Y, Kato T (1991) Effect of water-soluble and water insoluble fractions of Spirulina over serum lipids and glucose resistance of rats. J Jap Soc Nutr Food Sci 44:273-277

Tymm FJM, Bishop SL, Murch SJ (2020) A single laboratory validation for the analysis of underivatized $\beta-\mathrm{N}$-methylamino-L-alanine (BMAA). Neurotox Res In press

Whitton BA (2002) Phylum cyanophyta (cyanobacteria). In: John DM, Whitton BA, Brook AJ (eds) The freshwater algal flora of the British Isles. Cambridge University Press, Cambridge, UK, pp 25-122

WHO (2007) Protein and amino acid requirements in human nutrition. World Health Organ Tech Rep Ser 935:284 pp

Wood R (2016) Acute animal and human poisonings from cyanotoxin exposure- a review of the literature. Environ Int 91:276-282

World Food Programme (2019) WFP Chad country brief, July 2019. World Food Programme, www.wfp.org.chad

Publisher's Note Springer Nature remains neutral with regard to jurisdictional claims in published maps and institutional affiliations. 